\title{
On the classification and genesis of soils developed over acid volcanic material under humid tropical conditions II
}

\author{
K. H. TAN and J. VAN SCHUYLENBORGH \\ University of Indonesia, Bogor, and Agricultural University, Wageningen, \\ Netherlands respectively
}

\begin{abstract}
Summary
Formation of zonal soils on acid volcanic (rhyolitic and dacitic) tuffs is discussed. Depending on temperature, 4 belts can be distinguished, viz. a belt with Podzols at an elevation of $1500-2000 \mathrm{~m}$ above sea level, a second belt with Podzol-Brown Podzolic intergrades between 1100 and $1500 \mathrm{~m}$ altitude, a third belt with Brown Podzolic soils at an elevation of 1100 and $500 \mathrm{~m}$ above sea level, and finally a fourth belt with Red-Yellow Podzolic soils from $500 \mathrm{~m}$ altitude downward.

Intrazonal soils are formed on andesito-dacitic tuffs at low altitudes. Andosoils, Humic Gley Soils and Grey Hydromorphic soils can be distinguished, depending on drainage-impedence.

The soil genetics are discussed.
\end{abstract}

\section{Introduction}

The area studied is situated in the north of Sumatra and chiefly comprises the Residences Tapanuli and East Coast of Sumatra, viz. the uplands around the Toba lake and its eastern part, descending to the Strait of Malacca. This eastern part has already been thoroughly investigated by DRUIF $(1932,1934,1938)$. He compiled an agrogeological map of it, taking the petrographic-genetic principle as a basis for the division of the soils. Thus he distinguished between rhyolitic-, dacito-rhyolitic, recent dacitic- etc. soils and their alluvial derivatives. A subdivision was made by including soil colour and texture in the scheme. In this way he described about 200 soil types, and this proved to be very valuable to agriculture.

No subsequent attempts were made to bring the classification into line with modern soil classification concepts nor was the genesis of the soils taken into consideration. Only Kiel and Rachmat (1948) and van Schuylenborgh and van RuMmelen (1955) respectively mentioned the occurrence of Podzols and Brown Podzolic soils in this region.

The present paper aims at giving a description of several autochtonous zonal soils and some intrazonal soils known as Black Dust soils; some observations will also be made on genesis.

\section{Geology, climate and parent material}

At a certain geological age of the island of Sumatra vast amounts of volcanic ash were blown out of one or more points in or near Toba lake (the pre-Toba eruption).

Received for publication 28th October, 1960.

Neth. J. agric. Sci., Vol. 9 (1961) No. 1 (February) 
FIGURE. Agro-geological sketch of a part of the east coast of Sumatra (DruIF, 1939)

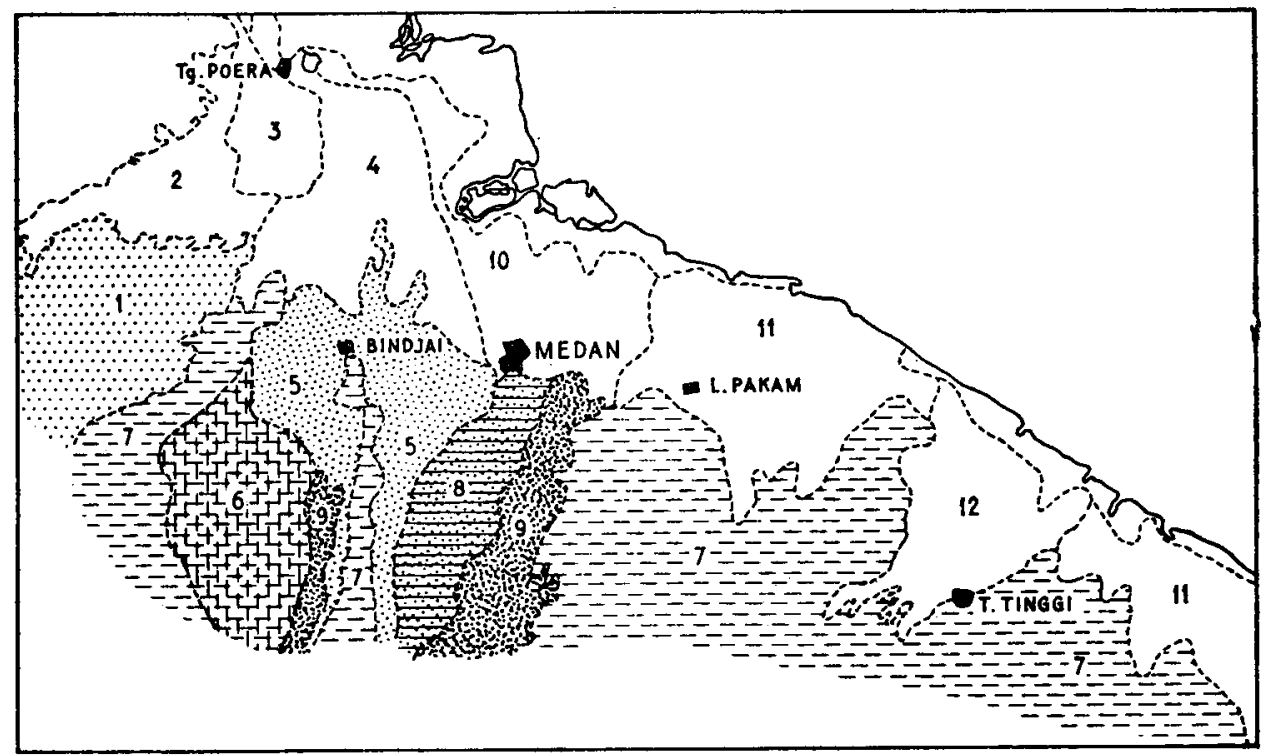

\section{Legend}

1. Tertiary soils; 2 . fluviatile tertiary soils; 3 . fluviatile tertiary and quaternary soils 4 . fluviatile andesitic-dacitic soils; 5 . "Black Dust" soils; 6 . dacitic liparite soils; 7. liparitic soils; 8 . Old dacitic soils; 9. Young dacitic soils; 10. fluviatile dacitic soils; 11. fluviatile liparitic soils; 12 . fluviatile mixed volcanic soils.

According to MoHR (1937) this took place during late tertiary periods (neogene and later); Druif (1932) dated this volcanic activity just at the beginning of the quaternary era. A very large area was covered with this rhyolitic volcanic material, viz. about $20,000 \mathrm{sq} . \mathrm{km}$ with an average depth of $50 \mathrm{~m}$. Since the surface covered by this material was originally very highly contoured the ash began to slide down; rainwater intensified this process by erosion and "lahar" formation. Originally high peaks in the landscape reappeared on the surface and former canyons were filled up. In any case the region became more dissected. After a period of rest a new era of volcanic activity began (the post-Toba eruptions). Dacitic material was then forced out during two periods, and this again formed "lahar" streams following already existing valleys and terrain folds. It is possible to distinguish ancient and recent dacitic tuffs and "lahars". After another stage of rest a third period of minor volcanic activity began at about the period of the Risz glaciation (MoHR, 1937); the volcanic material was of andesito-dacitic composition but with very fine quartz sand grains. This material is now found in two narrow "lahar" streams which meet and widen in the plains. A part of the region investigated is shown in the FIGURE (copied from DrUIF, 1939). We can therefore find several parent materials in the region investigated, viz. rhyolytic-, dacito-liparitic-, old dacitic-, young dacitic-, and andesito-dacitic-tuffs; furthermore tertiary materials (not investigated) and also the fluviatile derivatives of the tuffs mentioned (not investigated). The composion of the sand fraction of these different materials is shown comparatively in TABLE 1 (DRUIF, 1934). 


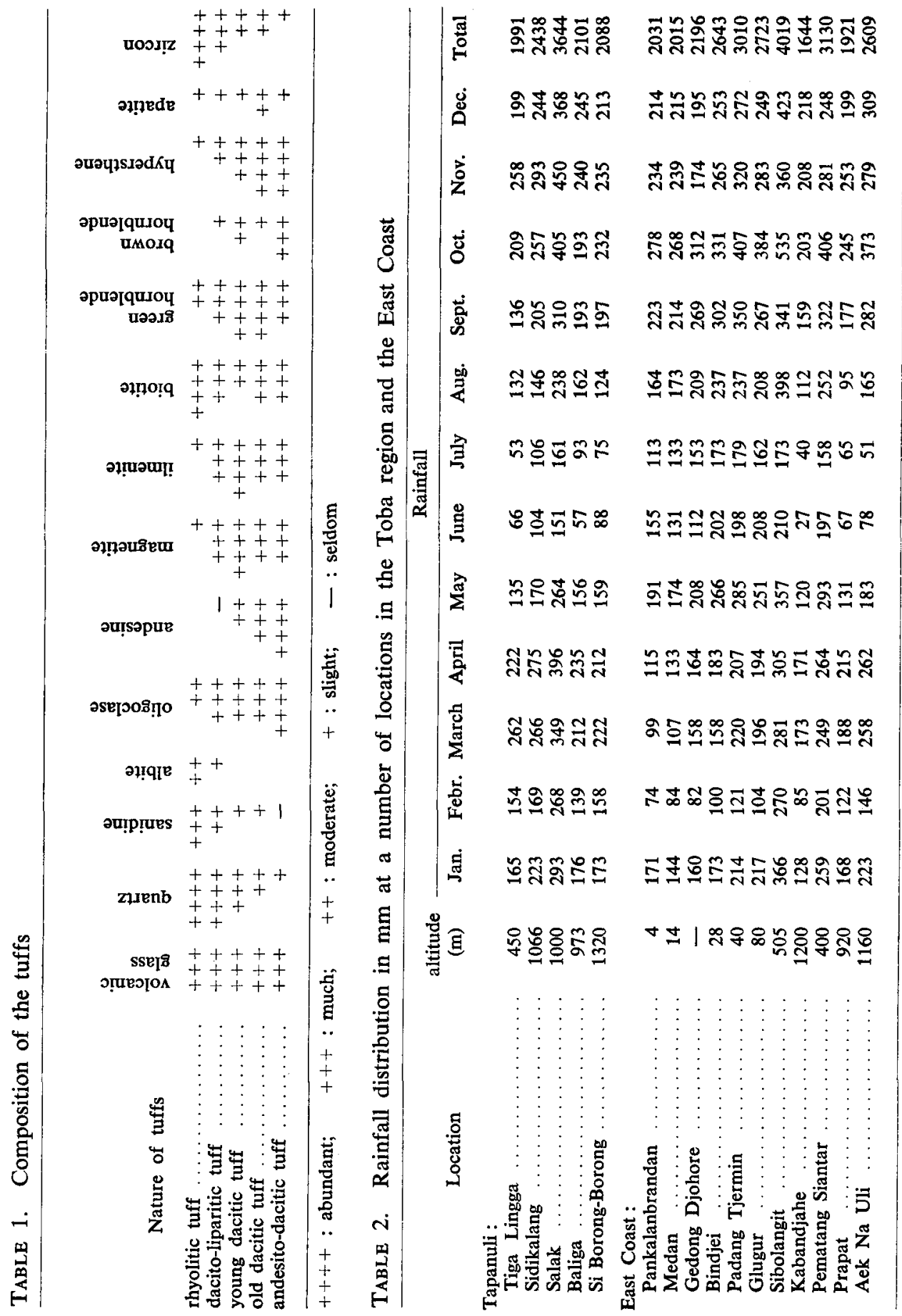

Neth. J. agric. Sci., Vol. 9 (1961) No. 1 (February) 
The tuffs extend from $2000 \mathrm{~m}$ to $50 \mathrm{~m}$ above sea level, so that climatic conditions differ with respect to temperature and rainfall. According to BrAaK (1923/25) the temperature can be estimated by means of the formula $t=26.3-\mathrm{h} \times 0.6^{\circ} \mathrm{C}$ in which $h$ is the elevation in hectometres.

Rainfall data is shown in TABLE 2, in which several locations in the region investigated are reported (BERLAGE, 1949).

The rainfall is found to differ from place to place, but if we accept CosTER's (1937) figure for the evapotranspiration of a tropical rain forest, viz. about $900 \mathrm{~mm}$ of moisture per annum, it will be evident that there is a continuous downward movement of moisture through the soil throughout the year. It may therefore be assumed in this case also that differences in rainfall will not result in difference in soil formation. Any differences in soil formation must have been caused by parent material and temperature.

\section{Materials and methods}

The discussions are based on 1. the profile morphology (colour, texture, structure and consistency), 2. the $\mathrm{pH}$ values, 3 . the organic matter profile, 4 . the mineralogical composition of the sand fraction, 5. the chemical composition of the clay fractions and 6. the $\mathrm{C} / \mathrm{N}$ values of the horizons. For analytical details reference may be made to Tan Kim Hong and van SchuYlenborgh (1959).

The profiles were taken at different altitudes and on different parent materials. Part of the profiles were supplied by courtesy of the Director of Soil Research Institute, Bogor, for which the authors tender their thanks.

The Munsell colour notations in the profile descriptions refer to the air-dry and wet state.

\section{Results and discussion}

\section{A. Zonal soils}

Examination of the profiles leads to the conclusion that schematically four belts can be distinguished. The highest belt extends from 2000 to $1500 \mathrm{~m}$ altitude and consists of Podzols. The effect of parent material could not be traced since at this altitude the material mainly consists of rhyolitic tuffs. An example is the PROFILE here-under.

Prof. 1. Tapanuli Residency, Laepondom. Foot of Mt. Sibartong. Altitude 1600 m. Vegetation: primeval tropical rain forest. Parent material: rhyolitic tuff. Rainfall $2500 \mathrm{~m}$. Temp. about $16.5^{\circ} \mathrm{C}$.

$\mathrm{A}_{00}+\mathrm{A}_{0}$ 0-20 cm Dark reddish-brown (5YR 3/4 - 5YR 3/3) raw humus. Partly decomposed. When dry it can only be moistened with great difficulty.

$\mathrm{A}_{2} 20-30 \mathrm{~cm}$ Grey to very dark grey (5YR 5/1 - 5YR 3/1) sandy loam. Weak fine crumb. Very friable. Abundance of roots. Difficult to moisten.

$B_{2 h} 30-50 \mathrm{~cm}$ Brown to very dark grey brown (10YR 5/3 - 5YR 3/2) sandy loam. Moderately developed coarse platy. Firm. Few roots. Difficult to moisten. Dark reddish grey (5YR 4/2) mottled.

$\mathrm{B}_{2 \mathrm{ir}} 50-55 \mathrm{~cm}$ Yellow to reddish yellow (10YR $\left.71 / 2 / 6-7.5 \mathrm{YR} 6 / 8\right)$ loam. Irregularly platy. Very firm. No roots.

$\mathrm{C}+55 \mathrm{~cm}$ White to pale yellow (10YR 9/1 - 2.5Y 7/4) sandy loam. Massive. Friable. Yellowish red (5YR 5/8) and yellow (10YR 7/8) mottled. A few pumice stones. 
The analytical results are given in TABLES 3 and 4. TABLE 3 shows the normal distribution in the profile of clay, organic matter, silicic-acid and sesquioxides. We can also see, that the composition of organic matter (as indicated by $\mathrm{C} / \mathrm{N}$ quotient) in the illuvial horizons differs from that in the eluvial horizons, a phenomenon frequently encountered in the Forest Podzols in temperate climates. Apparently one fraction of soil organic matter is mobile and responsible for the translocation of the sesquioxides. Iron is more mobile than aluminium.

The second belt, extending from $1500 \mathrm{~m}$ to $1100 \mathrm{~m}$ altitude and also chiefly consisting of rhyolitic tuffs, is occupied by Podzol-Brown Podzolic-Intergrades. An example on old dacitic tuff is profile 2.

Prof. 2. Tapanuli Residency, Malaunadeak-Samosir. Altitude $1450 \mathrm{~m}$. Vegetation: pine nursery (originally tropical rain forest). Parent material: old dacitic tuff. Excessively drained. Temp. $17.5^{\circ} \mathrm{C}$. $A_{11} 0-10 \mathrm{~cm}$ Grey brown to dark grey brown (10YR 41/2/2 - 10YR 3/21/2) silty clay loam. Weak, very fine crumb. Very friable. Abundance of roots.

$\mathrm{A}_{12} 10-15 \mathrm{~cm}$ Brown to dark brown (10YR $51 / 2 / 3$ - 10YR 3/3) silty clay loam. Weak fine crumb to granular. Friable. Many roots.

B $15-32 \mathrm{~cm}$ Light yellowish-brown to yellowish-brown (10YR 6/4 - 7.5YR 5/5) silty clay loam. Weak fine nutty. Friable. Many roots.

BC $32-56 \mathrm{~cm}$ Very pale brown to brown (10YR $71 / 2 / 4-7.5 \mathrm{YR} 5 / 4)$ silty clay loam. Weak fine nutty. Firm. Few roots.

$\mathrm{C}(?)+56 \mathrm{~cm}$ Pale yellow to light yellowish brown $(2.5 \mathrm{YR} 8 / 5-10 \mathrm{YR} 6 / 3 \mathrm{~L} / 2)$ silty clay loam. Weak fine prismatic. Very firm. Very few roots.

It would seem that the lowest horizon has a different composition than the solum (see TABLE 4) and moreover TABLE 3 shows a distinct illuviation of sesquioxides. In this case also iron seems to be more mobile than aluminium. The $\mathrm{C} / \mathrm{N}$ ratio decreases with depth, a normal feature of podzolic soils in temperate climates.

The distribution of sesquioxides and silicic acid is very comparable with that of the Podzols, but as there is no bleached horizon these soils are classified as Podzol-Brown Podzolic Intergrades by the present authors.

The third belt extends from $1100 \mathrm{~m}$ to about $500 \mathrm{~m}$ altitude and consists of Brown Podzolic soils. Two examples will be given here.

Prof. 3. East Sumatra, Pematang Sidamanik. Altitude $950 \mathrm{~m}$. Hilly land; profile on flat top of a hill. Vegetation: Old tea shrubs and Imperata cylindrica. Parent material: rhyolitic tuff. Excessively drained. Rainfall $3051 \mathrm{~mm}$. Temp. $20.5^{\circ} \mathrm{C}$.

$A_{1} 0-15 \mathrm{~cm}$ Dark brown (10YR 3/3 - 7.5YR 3/2) loam. Moderate fine crumb. Very friable. Many roots.

$B_{1} 15-40 \mathrm{~cm}$ Yellowish-brown to strong brown (10YR 5/4 - 7.5YR 5/6) loam. Weak fine nutty. Friable to slightly sticky. Few roots.

$B_{3} 40-75 \mathrm{~cm}$ Very pale brown to yellowish brown (10YR 7/4 - 10YR 5/4) sandy loam. Weak fine blocky. Friable to slightly sticky. Few roots.

C $+75 \mathrm{~cm}$ Very pale brown (10YR $8 / 4-10 \mathrm{YR} 7 / 4)$ loamy sand. Massive. Friable. Very few roots.

Prof. 4. East Sumatra, Durian tinggung. Altitude $600 \mathrm{~m}$. Flat to slightly undulating land. Vegetation: cultivated land. Parent material: rhyolitic tuff. Excessively drained. Rainfall about $4000 \mathrm{~mm}$. Temp. $22.5^{\circ} \mathrm{C}$.

$A_{p} 0-23 \mathrm{~cm}$ Light brown grey to very dark grey brown (10YR 6/2 - 10YR 3/2) loam. Fine crumb. Very friable. Abundance of roots. 


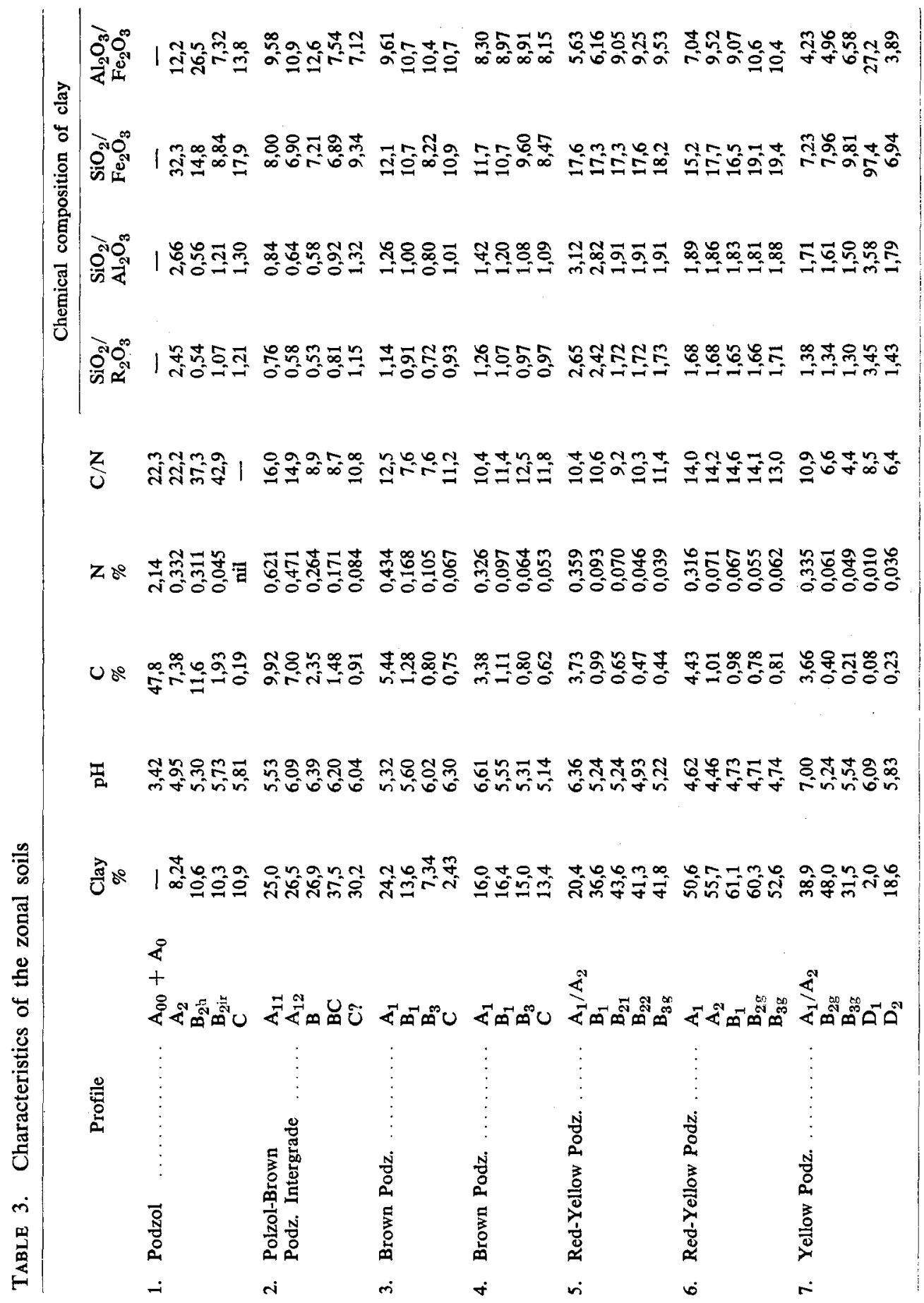




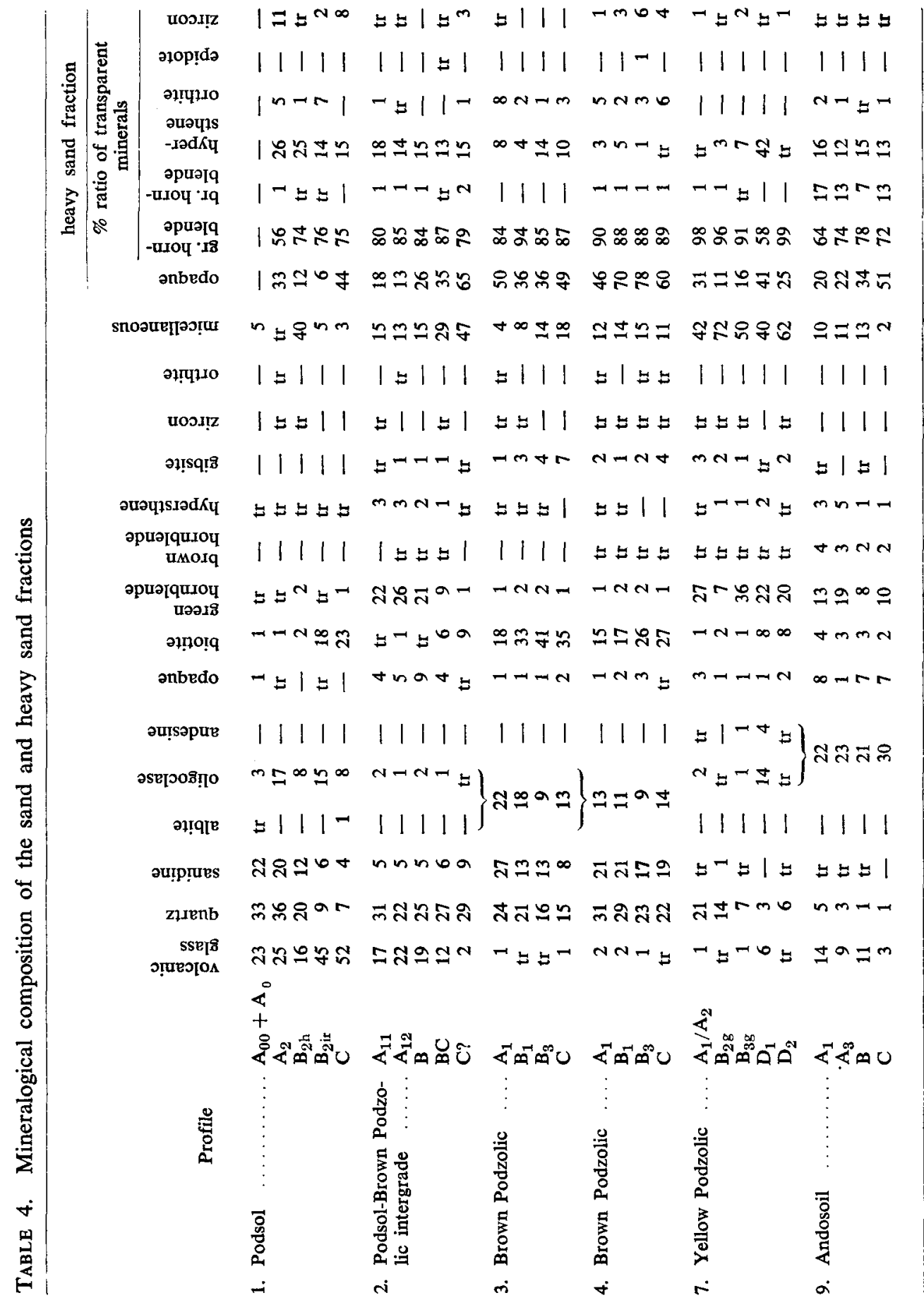


$B_{1} 23-88 \mathrm{~cm}$ Pale brown to brown (10YR 6/3 - 7.5YR 3/2) loam. Moderate fine nutty. Friable. Few roots.

$B_{3} 88-132 \mathrm{~cm}$ Very pale brown to brown (10YR $\left.7 / 3-7.5 Y R 5 / 4\right)$ loam. Very fine nutty. Friable to firm. Very few roots.

$\mathrm{C}+132 \mathrm{~cm}$ Very pale brown to pale brown (10YR 8/3-10YR 6/3) loam. Massive. Friable to firm. No roots.

There is no illuviation of clay in these profiles and aluminium is slightly more mobile than iron. This characteristic is an important difference between the soils of the third and those of the second and first belts. The trend of the $\mathrm{C} / \mathrm{N}$ ratia is indistinct as the soils are or were under cultivation and natural conditions had consequently been disturbed.

Finally a fourth belt of Red and Yellow Podzolic soils may be observed from about $500 \mathrm{~m}$ elevation to the boundary of the alluvial soils. Except on the andesito-dacitic tuffs they occur on both tertiary and volcanic parent materials.

Three examples will be given here.

Prof. 5. East Sumatra, Gonting Silaugomon. Altitude $300 \mathrm{~m}$. Dissected rolling land. Vegetation: Secondary forest with shrubs. Parent material: rhyolitic tuff. Well drained. Rainfall about $3000 \mathrm{~mm}$. Temp. $24.5^{\circ} \mathrm{C}$.

$A_{1} / A_{2} 0-15 \mathrm{~cm}$ Grey to very dark grey (10YR 3/1) sandy clay loam. Weak medium crumb. Very friable. Many roots.

$B_{1} 15-40 \mathrm{~cm}$ Very pale brown to reddish-yellow (10YR 7/4 $-7.5 \mathrm{YR} 6 / 6$ ) sandy clay. Weak fine nutty. Friable. Few roots.

$\mathrm{B}_{21} 40-65 \mathrm{~cm}$ Very pale brown to reddish-yellow (10YR 7/4 $-7.5 \mathrm{YR}$ 6/6) clay. Moderate fine nutty. Friable to firm. Few roots.

$B_{22} 65-90 \mathrm{~cm}$ Very pale brown to reddish-yellow (10YR 8/4 $-7.5 \mathrm{YR} 6 / 6$ ) sandy clay. Moderate medium nuttiy. Firm. Very few roots.

$\mathrm{B}_{3 \mathrm{~g}} 90-115 \mathrm{~cm}$ Very pale to reddish-yellow (10YR 8/4 - 7.5YR 6/6) sandy clay. Lumpy. Slightly sticky. Many fine, distinct reddish-yellow (7.5YR 8/6 - 5YR 6/7) mottles. No roots.

Prof. 6. East Sumatra, Pasirbidang. Altitude $200 \mathrm{~m}$. Hilly, with deep valleys and steep slopes. Profile on flat top of hill. Vegetation: Open primeval rain forest. Parent material: rhyolitic tuff. Moderately well drained. Rainfall about $3000 \mathrm{~mm}$. Temp. $25^{\circ} \mathrm{C}$.

$A_{1} 0-15 \mathrm{~cm}$ Dark grey brown to brown (10YR 4/2 - 7.5YR 4/2) clay. Weak fine crumb. Friable. Many roots.

$A_{2} 15-35 \mathrm{~cm}$ Very pale brown to reddish-yellow (10YR 7/4 $-7.5 \mathrm{YR} 6 / 6$ ) clay. Weak fine nutty. Friable. Few roots.

$B_{1} 35-65 \mathrm{~cm}$ Yellow to reddish-yellow (10YR 8/6 - 7,5YR 7/6) clay. Weak fine nuttiy. Firm. Few roots.

$B_{2 g} 65-85 \mathrm{~cm}$ Yellow to reddish-yellow (10YR 8/6 - 7.5YR 7/6) clay. Moderate fine nutty. Friable. Few, fine and distinctly rusty brown mottles. Few roots.

$B_{3_{g}} 85-100 \mathrm{~cm}$ Very pale brown to reddish-yellow (10YR 8/4 $-7.5 \mathrm{YR} 7 / 6$ ) clay. Weak fine nutty. Friable to firm. Few, fine and distinctly rusty brown mottles. No roots.

Prof. 7. East Sumatra, Simpang Kotadinging. Altitude $80 \mathrm{~m}$. Level to very slightly sloping land. Vegetation: cultivated. Parent material: Young dacitic tuff. Somewhat poorly drained. Rainfall about $2800 \mathrm{~mm}$. Temp. $26^{\circ} \mathrm{C}$.

$\mathrm{A}_{1} / \mathrm{A}_{2} 0-30 \mathrm{~cm}$ Very pale brown to yellowish-brown (10YR 7/4 $\left.-10 \mathrm{YR} 5 / 4\right)$ clay loam. Moderate fine nutty. Friable. Abundance of roots.

$\mathrm{B}_{2 \mathrm{~g}} 30-75 \mathrm{~cm}$ Yellow to strong brown (10YR 7/8 - 7.5YR 5/6) clay. Moderate medium blocky. Slightly sticky. Irregularly shaped concretions. Few roots. 
$\mathbf{B}_{3 \mathrm{~g}} 75-103 \mathrm{~cm}$ Yellow to brownish-yellow (10YR 8/6 - 10YR 6/6) clay loam. Weak medium nutty. Friable. Very few roots.

$\mathrm{D}_{1} 103-120 \mathrm{~cm}$ White to pale yellow $(2.5 \mathrm{Y} 8 / 2-2.5 \mathrm{Y}$ 7/4) loamy sand. Massive. Friable. Slightly yellow-mottled. No roots.

$\mathrm{D}_{2}+120 \mathrm{~cm}$ Yellow to yellowish-brown (10YR 71/2/6 - 10YR 5/6) silty loam. Weak fine crumb. Friable. No roots. Thin black-coloured fibres.

It can be seen from TABLE 4 that PROF. 7 is not a homogeneous one. The upper three horizons form a Yellow Podzolic soil. TABLE 3 shows that aluminium has a distinctly greater mobility than iron. This is accompanied by a constant $\mathbf{C} / \mathbf{N}$ ratio, as was pointed out in a previous article (VAN SCHUYLENBORGH, 1957).

The genesis of the soils may be explained on the basis of the theory propounded by MoHR (1922) and JofFe $(1931,1936)$ which was developed by one of the present authors and his co-workers $(1955,1957,1958,1959)$. According to this theory, under suitable conditions (high base-status, adequate air, water and temperature regimes) the organic matter decomposed completely, so that the soil-forming agent was carbonic acid. This explains why aluminium was more mobile than iron in tropical podzolic soils. The theory was supported by the constant $\mathrm{C} / \mathrm{N}$ ratio of soil organic matter and the composition of soil organic matter as compared with that of litter and roots, indicating a rapid decomposition to $\mathrm{CO}_{2}$ and water. $\mathrm{A}$ more direct proof is the determination of carbon dioxide in soil air. This concentration was determined (according to SCHUfFelen et al., 1954) in soils, situated at different altitudes, under constant humid conditions (W. Java). The results are given in TABLE 5. It appears that at a certain altitude conditions are most conductive to rapid mineralization of organic matter.

TABLE 5. $\mathrm{CO}_{2}$ content (volume percentage) of the atmosphere of tropical soils depending on elevation

\begin{tabular}{|c|c|c|c|c|c|c|}
\hline \multirow{2}{*}{$\begin{array}{l}\text { depth } \\
\text { (cm) }\end{array}$} & & \multicolumn{5}{|c|}{ elevation in metres } \\
\hline & & 1100 & 800 & 600 & 490 & 250 \\
\hline 10 & $\ldots \ldots \ldots \ldots \ldots$ & 0,6 & & & & 0,8 \\
\hline 15 & & & 0,9 & 3,6 & & \\
\hline 20 & $\ldots \ldots$ & 0,7 & & & 1,6 & \\
\hline 25 & (2) & & & & & 1,5 \\
\hline 35 & $\ldots \ldots \ldots \ldots$ & 0,9 & & 4,4 & & \\
\hline 40 & $\ldots \ldots \ldots \ldots \ldots$ & & 1,2 & & 2,2 & \\
\hline 50 & $\ldots \ldots \ldots \ldots$ & & & & & 2,4 \\
\hline 55 & $\ldots \ldots \ldots \ldots$ & 0,9 & & & & \\
\hline 60 & $\ldots \ldots \ldots \ldots \ldots$ & & 1,4 & 4,4 & 2,8 & \\
\hline 70 & $\ldots \ldots \ldots \ldots$ & 1,1 & & & & \\
\hline $\begin{array}{l}80 \\
90\end{array}$ & $\ldots \ldots \ldots \ldots \ldots$ & & 1,5 & 4,8 & 3,4 & 3,1 \\
\hline 100 & $\ldots \ldots \ldots \ldots$ & & 1,6 & & & \\
\hline 110 & $\ldots \ldots \ldots \ldots \ldots$ & & & & & 3,4 \\
\hline Mean & & 0,84 & 1,32 & 4,30 & 2,50 & 2,24 \\
\hline
\end{tabular}

The conditions in the region under investigation in this paper are less favourable to rapid mineralization of soil organic matter, especially at higher altitudes. The low base-status (acid parent materials) and lower temperatures (high altitudes) retard the mineralization process, so that organic acids may be a factor influencing soil forma- 
tion. This can be seen in the organic matter composition $(\mathrm{C} / \mathrm{N}$ ratio) of the soils of the first two belts. In this case the fairly well-known podzolization process led to the formation of Podzols and Podzol-Brown Podzolic Intergrades. The action of organic acids is responsible for the greater mobility of iron in these soils as compared to aluminium (cf. AARNio, 1913; JoNes and Willcox, 1929; Gallagher, 1942; BloomFIELD, 1953, 1954; STOBbe and WRIGHT, 1959).

Despite the low base-status of the soils the conditions of the lowest belt appear to favour a rapid mineralization process; the high temperature (high biological activity) overcome the detrimental effect of the low base-status. In the soils of this region the $\mathrm{C} / \mathrm{N}$ ratio is constant and, consequently, aluminium is more mobile than iron.

The Brown Podzolic soils of the third belt occupy an intermediate position, as already discussed by VAN SCHUYLENBORGH and VAN RUMMELEN (1955). In this instance both organic and carbonic acids play a part in soil formation, with the result that iron is as mobile as aluminium (constant $\mathrm{Al}_{2} \mathrm{O}_{3} / \mathrm{Fe}_{2} \mathrm{O}_{3}$ ratio).

\section{B. Intrazonal soils}

The most important intrazonal soils in East Sumatra are the "Black Dust soils" (DRUIF, 1932) or "Ando-soils". These have a high organic matter content and sometimes exhibit illuviation of clay (see PROF. 8 and 9, TABLE 7). They are the most recent soils, formed on the andesito-dacitic tuffs and lahars (for their mineralogical composition see TABLE 4, PROF. 9), and are restricted to the lowest parts of the region (the "lahars" followed the lowest parts of the country). Rainfall in this region ranges from 2000 to $3000 \mathrm{~mm}$ per annum without a pronounced dry season. It is still a problem how these soils were formed. MoHR (1937) dated the last volcanic activity at the Riss glacial period. By that time the climate was much drier in the Indonesian archipelago and MOHR assumed that as a result the moisture did not continually move downward as at present but intermittently downward and upward. During the ascent alkaline solutions rose to the surface causing carbonization of the dessicated vegetation. The resultant organic matter would be extremely resistant to destruction.

There are, however, objections to this theory. DRuIF (1932) assumed that the last volcanic eruptions did not take place during the Pleistocene period but during the Holocene, viz. when the climate was comparable to the present climate. Moreover it is difficult to understand why the organic matter had not been destroyed under the recent conditions which are so extremely favourable to biological activity. The present authors are therefore inclined to the theory that drainage conditions might have played an important part in the formation of these soils since the lahars and tuffs from which the soils are formed have filled up valleys in the original landscape and created a level terrain. Under such conditions drainage difficulties are quite conceivable.

Moreover, the parent material of these soils is more finely textured than the other volcanic materials, as is shown in TABLE 6. These tuffs will therefore drain more slowly than rhyolitic tuffs for example, and as a result the andesito-dacitic tuffs will be saturated with moisture for longer periods than the more coarsely textured volcanic materials. Organic matter destruction will then be slower and under the heavy tropical vegetation there will be some accumulation of organic matter. This does not mean that there is no mineralization, but only that the equilibrium between the supply of fresh material and decomposition has been established at a high level of organic matter. Moreover, the organic matter is not very mobile owing to the fairly high base-status of the andesito-dacitic tuff. 
TABLE 6. Texture of rhyolitic and andesito-dacitic tuffs (in percentages)

\begin{tabular}{|c|c|c|c|}
\hline fraction & & rhyolitic tuff & andesito-dacitic tuff \\
\hline 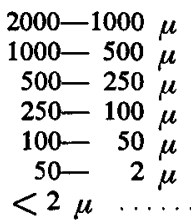 & 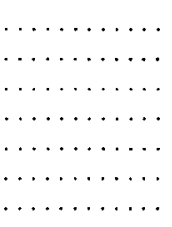 & $\left.\begin{array}{c}2,92 \\
13,7 \\
14,5 \\
14,5 \\
7,91 \\
33,9 \\
12,6\end{array}\right\} 22,41$ & 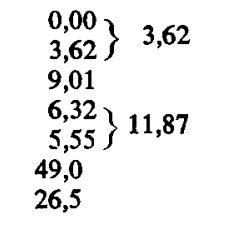 \\
\hline
\end{tabular}

The following profiles support the impeded drainage theory.

Prof. 8. East Sumatra, Glugur. Altitude $50 \mathrm{~m}$. Undulating land. Vegetation: secondary forest with Eupatorium, etc. Parent material: andesito-dacitic tuff. Well drained. Rainfall $2725 \mathrm{~mm}$.

$A_{1} 0-18 \mathrm{~cm}$ Dark grey brown to black (10YR 4/2 - 10YR 2/11/2) silt loam. Weak fine crumb. Loose, friable and soft. Many fine roots.

$A_{3} 18-28 \mathrm{~cm}$ Grey brown to very dark brown (10YR $\left.4 \frac{1}{2} / 2-10 \mathrm{YR} 2 / 2\right)$ silt loam. Moderate fine crumb. Friable and soft. Many fine roots.

B $28-31 \mathrm{~cm}$ Brown to dark yellowish-brown (10YR $5 / 3-10 \mathrm{YR} 3 / 4)$ loam. Weak fine nutty. Friable.

BC $31-76 \mathrm{~cm}$ Very pale brown to dark yellowish-brown (10YR $7 / 4-10 \mathrm{YR} 4 / 4)$ loam. Medium nutty to blocky. Slightly sticky. Small stone fragments.

Prof. 9. East Sumatra, Padang Tjermin. Altitude $40 \mathrm{~m}$. Level region. Vegetation: cultivated land. Parent material: andesito-dacitic tuff. Moderately well-drained. Rainfall $3010 \mathrm{~mm}$.

$A_{1} 0-25 \mathrm{~cm}$ Dark grey brown to very dark brown (10YR $\left.4 \frac{1}{2} / 2\right)$ loam. Weak fine crumb. Friable. Many roots.

A 3 25-45 cm Grey brown to dark brown (10YR 5/21/2 - 10YR 3/3) silt loam. Weak fine nutty. Friable.

AC $45-90 \mathrm{~cm}$ Very pale brown to brown (10YR $7 / 3-10 \mathrm{YR} 5 / 3)$ sandy loam. Weak fine blocky. Slightly sticky.

C $+90 \mathrm{~cm}$ White to grey (10YR $8 / 1-10$ YR 5/1) tuff.

Prof. 10. East Sumatra, Sg. Mentjirim. Altitude $30 \mathrm{~m}$. Undulating land. Profile located on the slopes. Vegetation: secondary forest. Imperfectly drained. Rainfall $2650 \mathrm{~mm}$.

$A_{11} 0-4 \mathrm{~cm}$ Dark grey brown to very dark brown (10YR 4/11/2 - 10YR 2/2) silt loam. Moderate fine crumb. Very loose and friable. Many fine roots.

$\mathrm{A}_{12} 4-28 \mathrm{~cm}$ Brown to dark brown (10YR 5/21/2 - 10YR 3/3) silty clay loam. Moderate medium crumb. Friable. Many fine roots.

$\mathrm{B}_{1 \mathrm{~g}} 28-40 \mathrm{~cm}$ Pale brown to dark brown (10YR 6/3 - 7.5YR 3/2) silty clay loam. Weak fine nutty. Friable. A few fine iron concretions.

$B_{2 g} 40-50 \mathrm{~cm}$ Very pale brown to dark grey brown (10YR $\left.7 / 3-10 \mathrm{YR} 4 / 2\right)$ silt loam. Fine nutty to blocky. Slightly sticky. Many distinct redox mottles. Iron-manganese concretions. Few roots.

$B_{3 g}+50 \mathrm{~cm}$ Very pale brown to grey brown (10YR 8/3-10YR 5/2) silt loam. Fine nutty to blocky. Firm and sticky. Large iron-manganese concretions. 
K. H. TAN AND J. VAN SCHUYLENBORGH

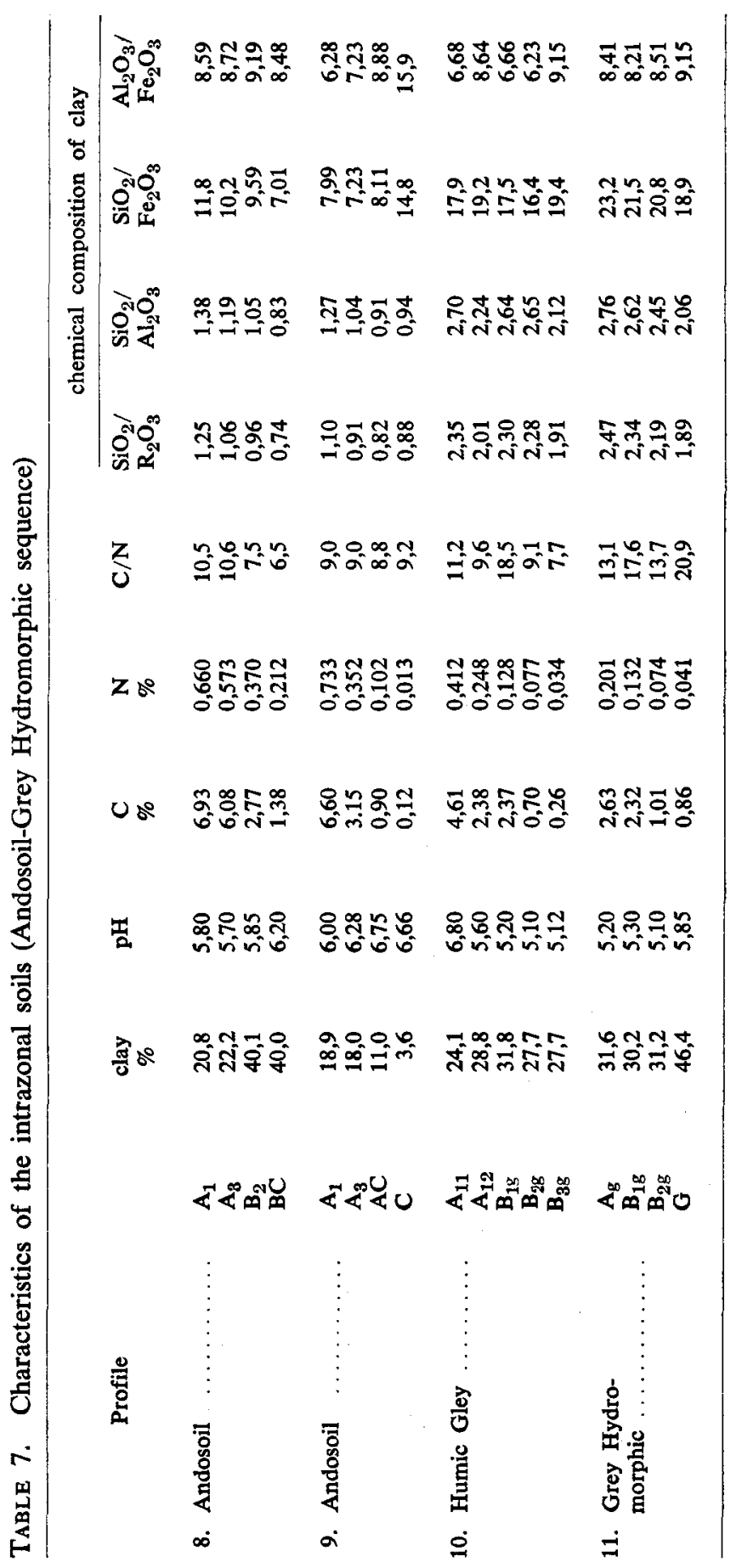


Prof. 11. East Sumatra, Sg. Mentiirim. Altitude $30 \mathrm{~m}$. Undulating land. Profile located in the depression. Vegetation: secondary forest. Very poorly drained. Groundwater level at the time of sampling: $42 \mathrm{~cm}$. Rainfall $2650 \mathrm{~mm}$.

$A_{\mathrm{g}} 0-24 \mathrm{~cm}$ Light grey to dark grey (10YR 61/2/1 - 10YR 4/1) silty clay loam. Weak fine crumb. Friable. Iron-manganese concretions. Fine roots.

$\mathrm{B}_{1 \mathrm{~g}} 24-31 \mathrm{~cm}$ Light grey to grey brown (10YR $\left.7 \frac{1 / 2}{1}-10 \mathrm{YR} 5 / 2\right)$ silty clay loam. Fine blocky. Slightly sticky, many medium and large iron-manganese concretions. Few fine roots.

$\mathrm{B}_{2 \mathrm{~g}} 31-39 \mathrm{~cm}$ White to light brownish-grey $(2.5 \mathrm{Y} 71 / 2 / 1-2.5 \mathrm{Y} 6 / 2)$ silty clay loam. Medium blocky. Firm and slightly plastic. Many large iron-manganese concretions.

$\mathrm{G}+39 \mathrm{~cm}$ White to light grey $(2.5 \mathrm{Y} 8 / 0-2.5 \mathrm{Y} 6 / 0)$ silty clay. Sticky and plastic. Many redox mottles.

This topo-sequence with Ando soils (PROF. 8 and 9) on the higher parts, Humic Gley Soils (PROF. 10) and Grey Hydromorphic Soils (PROF. 11) in the lower parts is the chief feature of this region. The latter two groups were already distinguished by DRuIF (1939) and called "Semisubhydric Black Dust Soils" and "Subhydric Black Dust Soils", but such terms do not adequately describe these soils.

Prof. 8 and 9 are the normal Andosoils; Prof. 9 may be a truncated profile, the black topsoil having been removed by erosion. This erosion process may be very drastic in this region, exposing the yellowish brown and yellow subsoils of the Andosoils (see also Oostingh, 1928; Druif, 1939).

TABLE 7 shows that all soils are podzolic, sesquioxides being more mobile than silicic acid. This supports the view that organic matter destruction takes a different course than it would have done under conditions of perfect drainage; in the latter case latosolic soils would have originated on this type of parent material. In the Andosoils aluminium seems to be more mobile than iron, which indicates that carbonic acid is still an important soil-forming agent under such conditions. In the hydromorphic soils iron and aluminium are equally mobile; apparently both organic and carbonic acids are responsible for the translocation of $\mathrm{Fe}$ and $\mathrm{Al}$.

Hence we can summarize the situation in this region in the manner shown in TABLE 8 .

TABLE 8. Scheme of soil formation in the area investigated

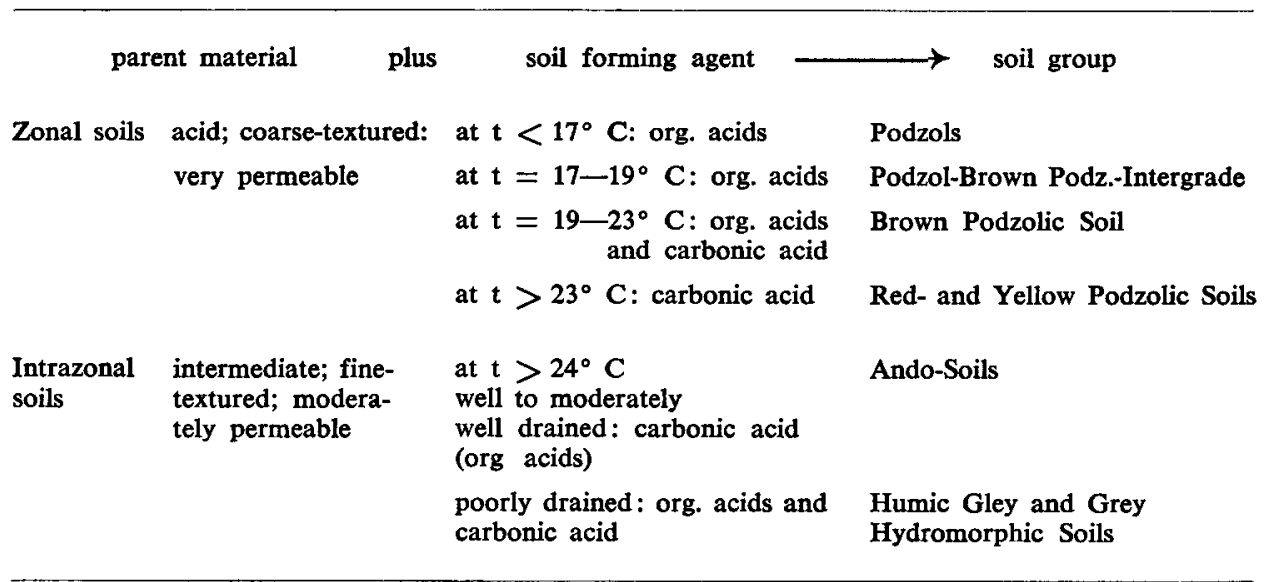




\section{RE F ER E N C E S}

AARNIO, B.

BERLAGE Jr., H. P.

BLOOMFIELD, C.

BRAAK, C.

COSTER, CH.

DRUIF, J. H.

GALLAGHER, P. $H$. JOFFE, J. $\mathbf{S}$

JONES, H. T. and

J. S. WILLCOX

KIEL, H. and H. RACHMAD

MOHR, E. C. J.

OOSTINGH, C. H.

SCHUFFELEN, A. C., et al.

SCHUYLENBORGH, J. VAN and F. F. F. E VAN RUMMELEN

SCHUYLENBORGH, J. VAN

STOBBE, P. C. and

J. R. WRIGHT

TAN KIM HONG and J. VAN 1959 Neth. J. Agric. Sci. 7, 1.

1913 Int. Mitt. Bodenk. 3, 131.

1953 J. Soil Sci. 4, 5, 17.

1954 J. Soil Sci. 5, 39, 46, 50.

1937 Tectona. 30, 2.

1931 Soil Sci. 32, 303.

1948 Landbouw. 20, 283. dam.
1949 Dept. Verk., Energie en Mijnb.; Met. en Geophys. Dienst; Kon. Magn. Obs. Verh. No. 37. Batavia.

1923/25 Versl. Kon. Magn. en Meteor. Obs. No. 8, 319.

1932 Meded. Deli Proefstat. 2e Serie No. 75, pp. 158.

1934 Bull. Deli Proefstat. No. 32, pp. 195.

1939 De Bodem van Deli. Buitenzorg.

1942 Proc. Roy. Irish Acad. 48 B, 213.

1944 Pedology. New Brunswick, Canada.

1929 J. Soc. Chem. Ind. 48, 304.

1922 De bodem van Java en Sumatra. Amsterdam.

1937 De bodem der tropen in het algemeen, en die van Nederlandsch-Indië, in het bijzonder. Deel II. Derde stuk. Amster-

1928 Meded. Deli Proefstat. 2e Serie No. 54, pp. 61.

1954 Landbouwk. Tijdschr. 66, 36.

1955 Neth. J. Agric. Sci. 3, 192.

1957 Neth. J. Agric. Sci. 5, 195.

1958 Neth. J. Agric. Sci. 6, 99.

1959 Soil Sci. Soc. Amer. Proc. 23, 161.

SCHUYLENBORGH 